DOI: $10.20472 / E S .2017 .6 .1 .002$

\title{
TECHNOLOGICAL PROGRESS IN CROATIAN PERENNIAL AGRICULTURE
}

\author{
TOMISLAV HERCEG, IVA VUKSANOVIC
}

\begin{abstract}
:
The agricultural sector in Croatia has declined or stagnated since the 1980s. Despite the high subsidies and EU accession, it failed to improve its production level, but the underlying causes of the subsidy inefficiency remain unclear. Trade liberalization and bear prices of agricultural products in the EU are some of the frequently cited arguments. On the other hand, government interventions in the form of direct subsidies have always been significant. Following the prevailing theoretical body of literature, we assumed that these interventions were at least in part aimed at achieving sustainable competitive position of the agriculture sector vis-à-vis foreign markets. Therefore, this paper analyzes Croatian perennial agriculture in detail with the aim to reveal whether subsidies in this sector led to technological progress and productivity increase. A panel data set for all Croatian legal entities doing business in the field of perennial agriculture in the 2008-2014 period was used to construct a production function in order to extract the total factor productivity and determine whether the $\mathrm{K} / \mathrm{L}$ ratio is properly set. It is shown that the $\mathrm{K} / \mathrm{L}$ ratio is entirely inadequate, while also indicating the decreasing returns to scale which should have been overcome with technological progress (TFP). The TFP in perennial agriculture remained constant throughout the period despite the changes in subsidies. Moreover, the majority of perennial subsectors have displayed significant decrease in the TFP. Finally, a TFP model was built to determine the factors that affect the TFP growth. By employing a set of 301 variables which describe the companies' internal and external properties, only two remained significant: export and subsidies, but with almost inexistent effect, revealing that exports and current subsidy distribution cannot be a drive for perennial or for non-perennial agriculture growth in Croatia.
\end{abstract}

\section{Keywords:}

Total factor productivity, perennial agriculture, Croatia, sectoral policies, agricultural subsidies, Cobb-Douglas production function.

JEL Classification: D24, Q13

\section{Authors:}

TOMISLAV HERCEG, Faculty of Economics and Business, University of Zagreb, Croatia, Email: therceg@net.efzg.hr IVA VUKSANOVIC, Faculty of Economics Belgrade, University of Belgrade, Yugoslavia, Email: ivav@ekof.bg.ac.rs

\section{Citation:}

TOMISLAV HERCEG, IVA VUKSANOVIC (2017). Technological progress in Croatian perennial agriculture. International Journal of Economic Sciences, Vol. VI(1), pp. 18-32., 
10.20472/ES.2017.6.1.002 


\section{Introduction}

Government interventions in the agriculture sector in Croatia still echo the old kind of industrial policies. It is a typical sectoral policy with direct subsidies at its core. Furthermore, it is completely contrary to the theoretical concepts of the role of the government interventions prevailing in the literature since the 1990s. Namely, the majority of papers discussing this topic agree on the fact that direct subsidies more often than not provide weak technological and productive spillovers, while they simultaneously reduce the possibility for close monitoring and make room for rentseeking and corruption (for example, see Rodrik, 2004; Aiginger, 2006; Ketels, 2006). Moreover, the latest conceptual works suggest that sectoral policies could produce desirable results in the knowledge-intensive, technology-driven areas of manufacturing. In the more traditional sectors, such as agriculture, a horizontal approach in terms of framework policies and provision of physical and soft infrastructure is suggested. For example, Fan et al. (2008) found that agricultural research, education and rural roads were the most effective public spending in promoting agricultural growth in India.

A number of papers treat the problem of subsidies and efficiency decrease, as it will be demonstrated in the following section. These papers most often implement some sort of inputoutput data analysis that compares returns in agricultural production to public investments and subsidies in this sector. Few papers provide thorough analysis of the limited scope of the sectoral approach in shaping government incentives in traditional sectors in terms of technological progress (Brümmer, 2002; Pereira, 2002; Latruffe et al., 2008; Bojnec and Latruffe, 2009; Swinnen and Vranken, 2010). Moreover, regardless of the geography these papers focus on research-wise, the period of analysis ends at best at the turn of the century. There is almost no research covering the period after the global economic crisis.

The subject of this paper is perennial agriculture in Croatia. Perennials play an important role in competitive positioning of the national economy, since $32 \%$ of revenues come from the foreign markets, more than any other kind of crop. On the other hand, preliminary analyses of the agriculture sector in Croatia indicate poor and relatively worsened productivity when compared to the other parts of the agriculture sector. High export orientation, followed by low productivity, was a primary motive for the analysis. Moreover, perennial agriculture dominates the import structure in Croatia.

This paper aims to provide an in-depth analysis of the perennial agriculture sector in Croatia for the 2008-2014 period in order to discover whether the long-lasting subsidies in this sector resulted in technological progress. We have reason to assume that the significant number of subsidies was at least partially aimed at achieving sustainable competitive position. Following the conceptual framework given by Rodrik (2004), we hypothesize that, in the long run, the government interventions that are based on subsidies do not lead to technological progress in the traditional sectors, such as perennial agriculture.

After a brief introduction, the paper is structured as followed. In the second section, we provide a literature review of the effects of subsidies in agriculture on efficiency improvement and technological progress. The third section deals with key characteristics and performances of perennial agriculture sector in Croatia in the 2008-2014 period. The fourth, fifth and sixth sections respectively introduce data and methodology, deliver econometric estimates of the Cobb-Douglas production function and compare the obtained results with alternative production function estimate 
results. Finally, in the seventh section we develop a total factor productivity model. The eighth section is dedicated to the discussion of the obtained results. The ninth section concludes the paper.

\section{Literature review}

Subsidies have been generally criticized for distorting competition and thus removing the incentives for efficient exploitation of resources. De Gorter et al. (1992) mark production subsidies in agriculture as a predatory policy "that incurs deadweight losses". Moreover, today it is widely accepted that even in the absence of such anomalies, vertical policy measures in traditional sectors of the economy cannot produce desirable spillover effects on technological progress and productivity growth.

The adverse impact of subsidies on efficiency was studied broadly in the literature (for example, Bezlepkina et al., 2005 and San Juan Mesonada et al., 2005). Emvalomatis et al. (2008) performed their study on the cotton production in Greece and established a reduced efficiency of the producers when subsidies were based on the area planted. Fan et al. (2008) analyzed the effects of the subsidies in agriculture in India in the 1951-1993 period, and concluded that subsidies played an important and positive role only in the initial stage of the adoption of a new technology by small and economically weak farmers. Pereira et al. (2002) also obtained similar results in certain regions of Brazil in the 1970-1996 period.

A separate field of study analyzes the impact of subsidies on technical efficiency and technological progress, and isolates positive or negative correlations between subsidies and agricultural production; Bojnec and Latruffe (2009) identified improvement in technical efficiency in Slovenia for the 1994-2003 period; Tonini and Jongeneel (2006) revealed a TFP improvement in the 1993-2003 period. Contrary to that, Swinnen and Vranken (2010) found a TFP deterioration in Slovenia in the 1989-2001 period. On the other hand, over the same period, the said authors found a positive TFP growth in the Balkans and the CEE countries jointly. The analyses conducted in Poland demonstrate similar research results: the increase of technical efficiency (Brümmer et al., 2002 for the 1991-1994 period and Latruffe et al., 2008 for the 1996-2000 period).

\section{Characteristics of perennial agriculture in Croatia}

Croatian agriculture boasts all geographical advantages for growing all moderate and Mediterranean climate crops; the Pannonian plane with rich soil, moderate climate and large rivers that traverse it provide conditions for intensive irrigated farming; mountainous regions and its valleys offer unique opportunities for extensive animal husbandry and potato farming, while red-soil plains intersected with rivers of Northern Dalmatia and Istria, as well as the Neretva valley, are ideal for perennials such as peaches, olives, apricots, cherries, vines and citruses.

Given the conditions above, cultivation of almost all classes of NACE ${ }^{1}$ rev. 2 is possible (Table 1).

\footnotetext{
${ }^{1}$ NACE $=$ Nomenclature statistique des activités économiques dans la Communauté européenne
} 
Table 1: NACE rev. 2 classification of agriculture, fishing and forestry

\begin{tabular}{|l|l|}
\hline Code & Name \\
\hline $\mathbf{1 2}$ & Growing of perennial crops \\
\hline 121 & Growing of grapes \\
\hline 122 & Growing of tropical and subtropical fruits \\
\hline 123 & Growing of citrus fruits \\
\hline 124 & Growing of pome fruits and stone fruits \\
\hline 125 & Growing of other tree and bush fruits and nuts \\
\hline 126 & Growing of oleaginous fruits \\
\hline 127 & Growing of beverage crops \\
\hline 128 & Growing of spices, aromatic, drug and pharmaceutical crops \\
\hline 129 & Growing of other perennial crops \\
\hline
\end{tabular}

However, Croatia is far from its potential agricultural output. As it can be seen in Table 2, Croatian agricultural production has been declining both in volume and share in GDP; from HRK 14.4B in $2010^{2}$ the production dropped to HRK 12.2B in 2014, marking a decrease from 4.4 to less than $3.6 \%$ of GDP (Herceg, Vrankić, Galetić, 2016).

\section{Table 2: Agricultural production in Croatia, 2010-2014}

\begin{tabular}{|l|l|l|}
\hline Year & $\begin{array}{l}\text { Agricultural } \\
\text { production in } \\
\text { HRK B }\end{array}$ & $\begin{array}{l}\% \text { of } \\
\text { GDP }\end{array}$ \\
\hline 2010 & 14.4 & $4.4 \%$ \\
\hline 2011 & 13.7 & $4.2 \%$ \\
\hline 2012 & 13.3 & $4.0 \%$ \\
\hline 2013 & 12.5 & $3.8 \%$ \\
\hline 2014 & 12.2 & $3.7 \%$ \\
\hline
\end{tabular}

Data source: Croatian Statistical Yearbook 2015 and FINA database

In 2014, perennial agriculture accounted for $5.5 \%$ of the agricultural land area where HRK $193 \mathrm{M}$ of goods were produced (Figure 1).

\footnotetext{
2 The exchange rate of the Euro against the Croatian Kuna (HRK) is approximately 7.5, with very slight periodical oscillations
} 
Figure 1: Perennial agricultural production in Croatia, 2008-2014

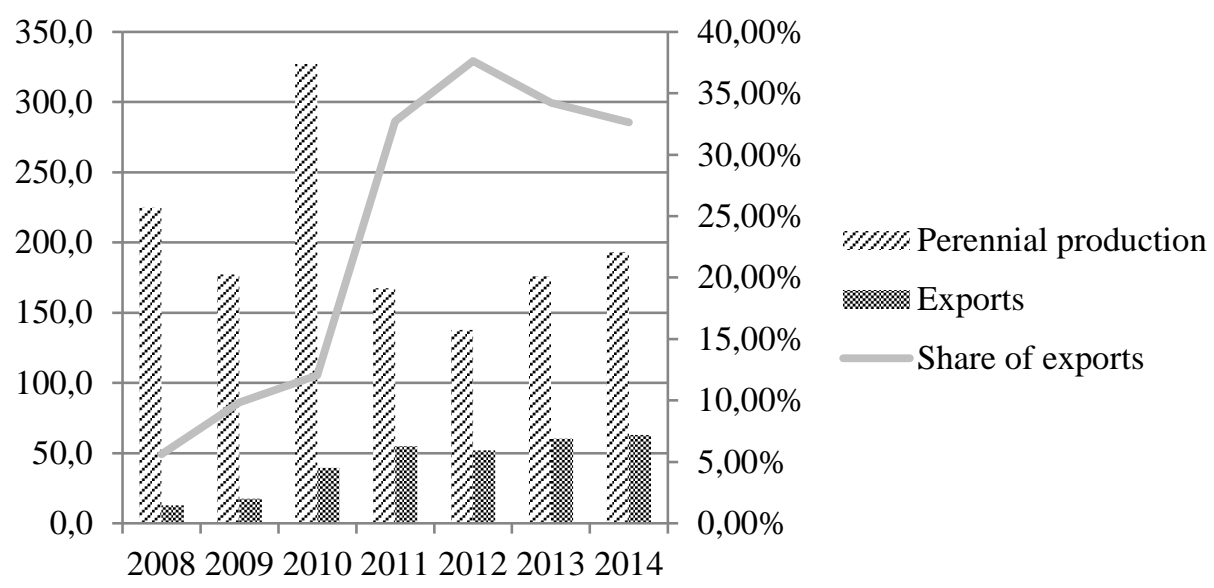

Data source: Authors' own calculations based on the Croatian Statistical Yearbook 2015 and FINA database Knowing that HRK 2.74B of non-perennial products were produced on $53.5 \%$ of land (see Figure 2 ), it is evident that non-perennial agriculture was by $46 \%$ more productive, which is opposite to the experiences of other EU countries that reached a much higher productivity in perennial agriculture.

\section{Figure 2: Non-perennial agricultural production in Croatia, 2008-2014}

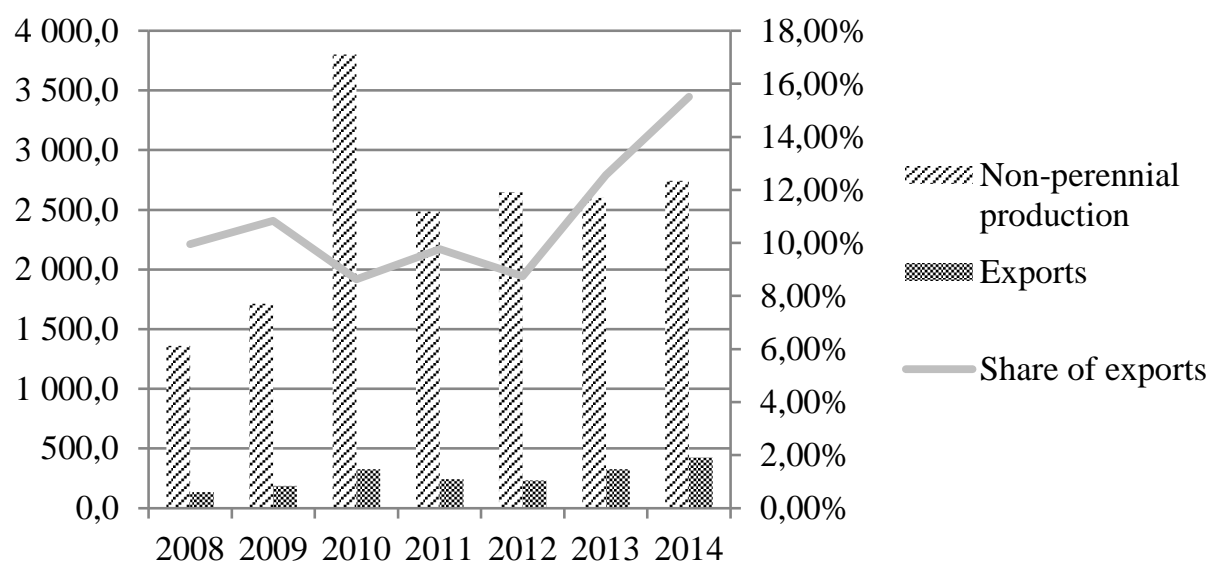

Data source: Authors' own calculations based on the Croatian Statistical Yearbook 2015 and FINA database However, perennial production reaches foreign markets more easily $(32.6 \%$ of the revenues is generated abroad) than it is the case with non-perennial production (15.5\% of products are exported). Perennial agriculture has also revealed different subsidy dependences over the years (Figure 3).

Figure 3: Share of subsidies in the total revenue for perennial and non-perennial agricultural production in Croatia, 2008-2014 


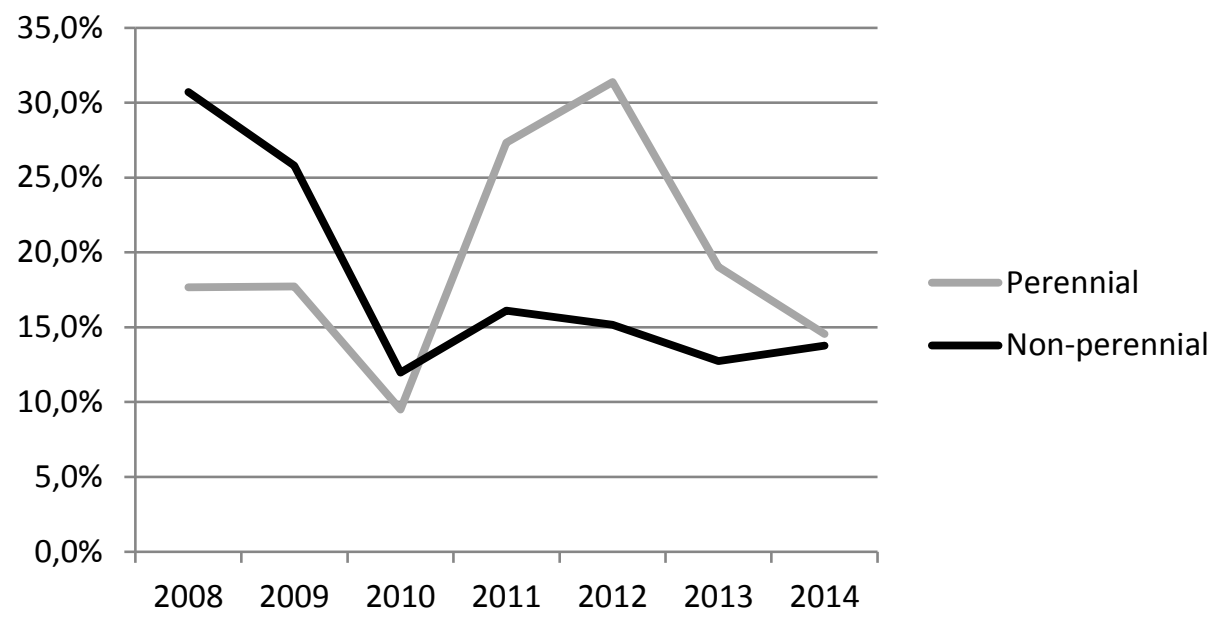

Data source: Authors' own calculations based on the Croatian Statistical Yearbook 2015 and FINA database

One can see that substantial subsidies in the previous period did not improve the position of Croatian perennial agriculture. Reasons for this, as well as for the higher export orientation and low productivity, are to be found in more detailed analyses.

\section{Data and methodology}

Armagan and Ozden (2007) analyzed the Turkish agriculture, namely crops, by using a CobbDouglas function to estimate its production function. In their study, they employed a number of inputs, including the average age of the farmers, their average education and land size, and distinguished small, medium and large producers. The analysis was based on cross-sectional data.

Echevarria (1998) constructed a production function for the Canadian agriculture. In this paper, a very common assumption was taken: scale elasticity $\varepsilon=1$ (constant returns to scale) and that production elasticities of each input correspond to its share in the total costs.

Parlinska and Dareev (2011) estimated agricultural production function for Poland and the Republic of Buryatia. A simple two-input Cobb-Douglas function was used to estimate production functions for both countries/regions using a time series from 2000 to 2009.

Herceg, Vrankić and Galetić (2016) estimated the non-perennial production function based on its high share in the overall area used for agriculture. It was concluded that subsidies make no impact on the improvement of its total factor productivity, unlike the Czech case described by Kroupová and Malý (2010).

Enaami, Mohamed and Ghani (2013) demonstrated an even higher number of advantages of using the Cobb-Douglas function as a basis for production function estimation. They also proposed manners of dealing with multiple issues that might occur under a multiple-input approach. Due to the said suggestions, the following simple model is used to estimate the Croatian perennial production function:

$\hat{Y}_{x t}=A_{x t} K_{x t}^{\kappa} L_{x t}^{\lambda}$

where $\mathrm{x}$ stands for the legal entity (company), $\mathrm{t}$ for year, $\mathrm{Y}$ for production volume, $\mathrm{A}$ for total factor productivity, $\mathrm{K}$ for capital, $\mathrm{L}$ for labor, $\mathrm{K}$ for contribution of capital (production elasticity of capital) 
and $\lambda$ for contribution of labor (production elasticity of labor). In addition to this, it is assumed that the total factor productivity changes over time with an exponential time path:

$A_{x t}=e^{a t+b}$

By combining (1) and (2), the following function is estimated:

$\hat{Y}_{x t}=e^{a t+b} K_{x t}^{\kappa} L_{x t}^{\lambda}$

After linearization, the estimated model was:

$\ln Y_{x t}=a t+b+\kappa \ln K_{x t}+\lambda \ln L_{x t}+u_{x t}$

A generalized method of least squares was employed with random effects, due to the abundant data set and expected differences between the companies. Multicollinearity, heteroscedasticity and autocorrelation tests were conducted, as well as parameter and joint tests for the validity of the model.

By using the obtained data, the total factor productivity may be calculated as a residual:

$A_{x t}=\frac{\hat{Y}_{x t}}{K_{x t}^{\kappa} L_{x t}^{\lambda}}$

In the second stage, a total factor productivity model was constructed using numerous regressors:

$A_{x t}=\sum_{i=1}^{n} Z_{x t, i}+u_{x t}$

Among many, the following regressors were taken into account: share of a company in the market, number of companies in the market, export volume, subsidies received ${ }^{3}$, growth of the economy and investment volume.

Data set for the analysis is obtained by FINA (Croatian Financial Agency) which collects company JOPPD 4 reports with a number of standardized data, such as revenues, newly created value, working hours and long-term assets. The data set used here covers the entire statistical population. The data are presented on a company (micro) level.

The report outline was altered several times. Therefore, an adjustment between certain years was necessary. After the adjustment, a 301-variable data set was obtained in the period from 2008 to 2014 (time dimension $t=7$ ) for 799 legal entities (cross section dimension $x=799$ ) which produced perennial agricultural crops. The unbalanced panel data set was used to estimate the CobbDouglas production function, which is the most commonly used method in similar analyses.

The time dimension covers the previously mentioned annual data from 2008 to 2014 ( $t=7)$, resulting in up to $6 \times 9=63$ data per variable. Since some companies were established later or were shut down before 2014 , or left this specific line of business after several years, the data may have gaps. Hence, each observed variable had the following form:

\footnotetext{
${ }^{3}$ Kroupová and Malý (2010) prove the importance of subsidies on Czech agriculture, again by using a multiple-input Cobb-Douglas production function.

${ }^{4}$ Official compulsory report that all companies have to consign annually, which contains all the items in every company's balance sheet, profit and loss account and cash flow statement, as well as many other data (more than 300 variables).
} 
$\left[\begin{array}{ccc}x_{1,1} & \cdots & x_{1,799} \\ \vdots & \ddots & \vdots \\ x_{7,1} & \cdots & x_{7,799}\end{array}\right]$

\section{Production function estimate}

Based on the previously described panel data set and methodology, the production function for Croatian perennial agriculture from 2008 to 2014 is estimated, taking the FINA data for value added as $Y$ (output), long-term assets as $\mathrm{K}$ (capital) and total working hours as $\mathrm{L}$ (labor). The econometric estimate of the model (4) was computed (panel data analysis with random effects). After the adjustments to solve the autocorrelation problem, a model $(7 \mathrm{~b})$ is estimated:

$\widehat{Y}_{t}=e^{0.37631 u_{t-1}+1.7857} K_{t}^{0.181} L_{t}^{0.376}$

F-test, t-test and the necessary autocorrelation and multicollinearity tests prove that this model is well-defined. Total factor productivity (gray) time path is horizontal:

$$
\begin{aligned}
& \widehat{A_{t}}=e^{0.37631 u_{t-1}+1.7857} \\
& E\left(u_{t-1}\right)=0 \\
& \widehat{A_{t}}=e^{1.7857}=5.96=\text { const. }
\end{aligned}
$$

Non-perennial agriculture in Croatia recorded a downward sloping TFP curve in the same period (Herceg, Vrankić, Galetić, 2016).

By using the obtained production function coefficients $(\mathrm{K}=0.181, \lambda=0.376)$, the total factor productivity for classes of perennial crops can be calculated according to (5). The TFP matrix includes all the columns, but since some of the subclasses did not exist in certain periods, there

\begin{tabular}{|c|c|c|c|c|c|c|c|c|c|}
\hline & Grapes & $\begin{array}{l}\text { Tropical } \\
\text { and } \\
\text { subtrop. f. }\end{array}$ & $\begin{array}{l}\text { Citrus } \\
\text { f. }\end{array}$ & $\begin{array}{l}\text { Pome } \\
\text { and } \\
\text { stone } \\
\text { f. }\end{array}$ & $\begin{array}{l}\text { Other } \\
\text { f., } \\
\text { bush } \mathrm{f} . \\
\text { and } \\
\text { nuts }\end{array}$ & Oleaginous & $\begin{array}{l}\text { Beve } \\
\text { rage } \\
\text { f. }\end{array}$ & $\begin{array}{l}\text { Spices, } \\
\text { aromatic, } \\
\text { drug and } \\
\text { pharmaceuti } \\
\text { cal crops }\end{array}$ & $\begin{array}{l}\text { Other } \\
\text { perennials }\end{array}$ \\
\hline 2008 & 3,820 & & & 3,997 & 2,845 & 203 & 528 & 849 & 1,820 \\
\hline 2009 & 3,508 & & & 2,366 & 2,134 & 696 & & 971 & 2,240 \\
\hline 2010 & 3,324 & & & 3,106 & 1,783 & 1,417 & & 1,220 & 2,132 \\
\hline 2011 & 2,831 & & 13,234 & 3,056 & 2,280 & 1,122 & & 918 & 2,710 \\
\hline 2012 & 3,192 & & 12,685 & 3,070 & 2,106 & 1,002 & & 1,125 & 1,107 \\
\hline 2013 & 2,757 & & 9,412 & 2,966 & 2,179 & 862 & & 694 & 1,887 \\
\hline 2014 & 2,791 & 40 & 9,268 & 2,700 & 2,198 & 1,181 & & 1,934 & 1,916 \\
\hline
\end{tabular}
are many gaps in the data matrix (Table 3 ).

Table 3: Production function residuals for Croatian perennial agriculture, 2008- 2014

Dynamics of the TFP for each subclass (Grapes, Citrus fruits, Pome and stone fruits, Other fruits, bush fruits and nuts, Oleaginous fruits, Spices, aromatic, drug and pharmaceutical crops and Other perennials) is given in Figure 4. Tropical and subtropical fruits, as well as beverage fruits, are omitted since they include a single data in the set (there was no production registered in other years). 
Figure 4: Total factor productivity of Croatian perennial agriculture per class, 2008-2014

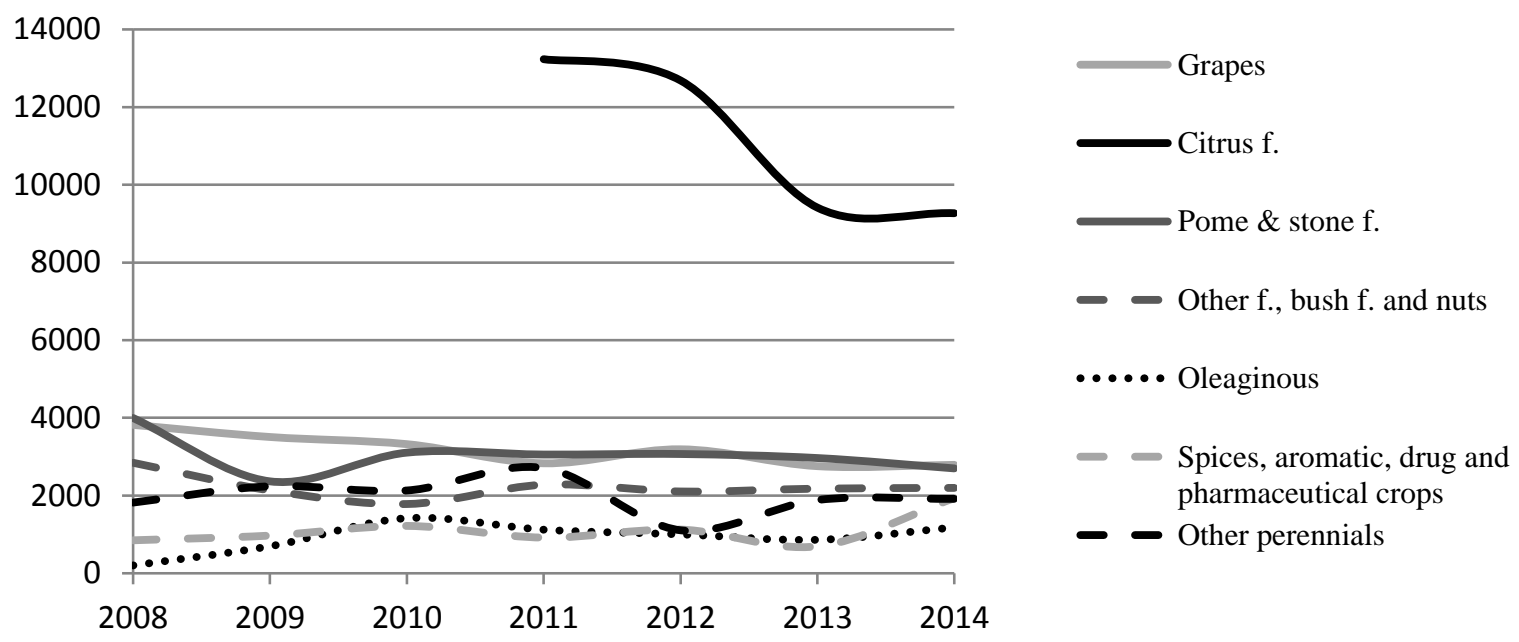

In order to be able to observe the dynamics in detail, a base index TFP matrix is calculated (Table 4).

Table 4: Base indices $(2008=100)$ of production function residuals for Croatian perennial agriculture, 2008-2014

\begin{tabular}{|c|c|c|c|c|c|c|c|c|c|}
\hline & Grapes & $\begin{array}{l}\text { Tropical } \\
\text { and } \\
\text { subtrop } \\
\text {. f. }\end{array}$ & $\begin{array}{l}\text { Citrus } \\
\text { f. }\end{array}$ & $\begin{array}{l}\text { Pome } \\
\text { and } \\
\text { stone } \\
\text { f. }\end{array}$ & $\begin{array}{l}\text { Other f., } \\
\text { bush f. } \\
\text { and nuts }\end{array}$ & Oleaginous & $\begin{array}{l}\text { Beve } \\
\text { rage } \\
\text { f. }\end{array}$ & $\begin{array}{l}\text { Spices, } \\
\text { aromatic, } \\
\text { drug and } \\
\text { pharmaceuti } \\
\text { cal crops }\end{array}$ & $\begin{array}{l}\text { Other } \\
\text { perennials }\end{array}$ \\
\hline 2008 & 100 & & & 100 & 100 & 100 & 100 & 100 & 100 \\
\hline 2009 & 92 & & & 59 & 75 & 344 & & 114 & 123 \\
\hline 2010 & 87 & & & 78 & 63 & 700 & & 144 & 117 \\
\hline 2011 & 74 & & 100 & 76 & 80 & 554 & & 108 & 149 \\
\hline 2012 & 84 & & 96 & 77 & 74 & 495 & & 132 & 61 \\
\hline 2013 & 72 & & 71 & 74 & 77 & 426 & & 82 & 104 \\
\hline 2014 & 73 & 100 & 70 & 68 & 77 & 583 & & 228 & 105 \\
\hline
\end{tabular}

Although the overall TFP did not variate during the period, the subclasses displayed significant data variations; the TFP in grapes production fell down by $27 \%$ in the period from 2008 to 2014 . In the same period, bush fruits and nuts dropped even more in productivity - by $32 \%$. Citrus fruits recorded a decrease in productivity by $30 \%$ in the period from 2011 to 2014 . Other perennials stagnated (increase by $5 \%$ in six years), but oleaginous fruits (namely olives) displayed an impressive increase in productivity, reaching an almost sixfold rise in six years. Spices and pharmaceutical crops also recorded a significant increase during the observed period, by $128 \%$ (Table 4/Figure 5). 
Figure 5: TFP of Croatian perennial agriculture per class (2008-2014), 2008=100

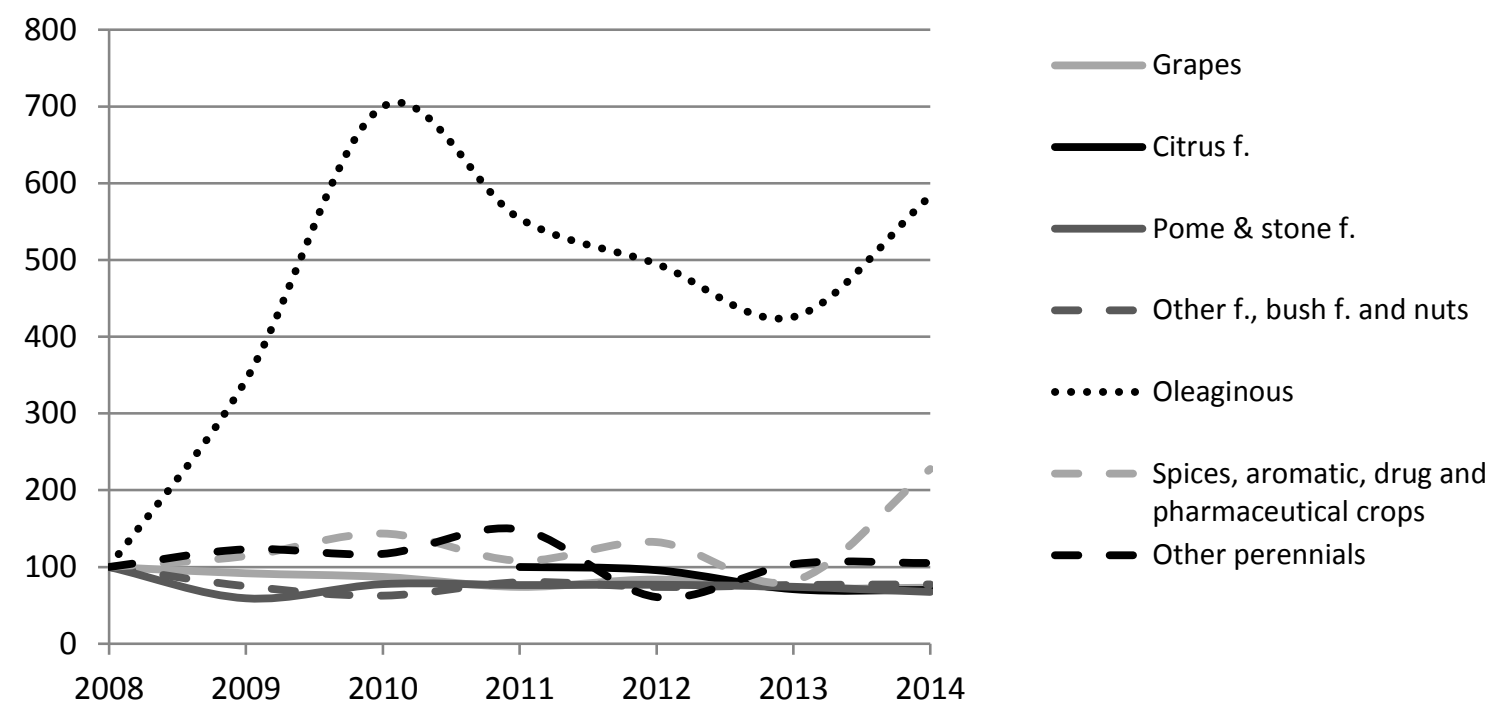

\section{Alternative production function construction}

Echevarria (1998) took a different, non-econometrical approach, where a share of input costs in the total costs was used as a proxy for input contribution. In this analysis, and many other subsequently, it was assumed that companies are on their expansion paths, where the costminimizing rule holds:

$\operatorname{MRTS}_{K L}=\frac{w}{r}$

Therefrom, returns to scale are constant. The comparison between these two approaches is given in Table 5.

Table 5: Comparison between share in costs and econometric production function coefficients for Croatian perennial agriculture, 2008-2014

\begin{tabular}{|l|l|l|}
\hline & Production elasticities & $\begin{array}{l}\text { Share in the total } \\
\text { costs }\end{array}$ \\
\hline $\mathrm{K}$ & 0.180 & 0.868 \\
\hline $\mathrm{L}$ & 0.544 & 0.132 \\
\hline Total & 0.724 & 1.000 \\
\hline
\end{tabular}

Data source: Authors' own calculations based on FINA database

Comparison reveals significant differences between the coefficients obtained by the econometric and the cost-minimizing approach, respectively; firstly, the econometric approach shows that returns to scale are not constant, but decreasing. Secondly, labor contribution is much higher than the share of labor costs in the total costs. Furthermore, contribution of capital is much smaller in the estimated function. These findings suggest that an excessive number of workers is used per unit of capital, which is due to poor education of the Croatian farmers. Hence, less capital is used since there is not enough human capital to run it, which causes decreasing returns to scale. Similar results are obtained for non-perennial agriculture. 
The significant difference between econometric and non-econometric function coefficients suggests that the econometric approach should be used for further analyses of the TFP in this paper.

\section{Total factor productivity model}

The estimation of the model defined in (6) employed more than 100 variables, as described in section Data and Methodology:

$T \hat{F} P_{t}=\beta_{0}+\beta_{1} x_{1}+\cdots+\beta_{j} x_{j}$

It was found that only export orientation and subsidies are significant in the TFP formation. The data for the analysis are in the same panel form (7a), where the TFP is obtained as a residual of model (7b), and the EXP and the SUB are export and subsidies volumes in the previously mentioned FINA data set.

After solving the issues of autocorrelation and heteroscedasticity, the model (12) was estimated and the following model (13) was obtained:

$T \hat{F} P_{t}=0.0000605 S U B+0.000305 E X P+0.3768332 T F P_{t-1}+332.7949$

There is a slight positive effect of the export and subsidy increase, but it is almost inexistent. In non-perennial agriculture, subsidies exert a three times higher influence on the TFP, but exports have a three times smaller influence on the TFP. Kroupová and Malý (2010) proved that in the Czech Republic, subsidies have a strongly positive effect on the TFP in agriculture. The reasons for the former should be found in the inefficient subsidy distribution and poor education in agriculture. Also, Croatia rarely irrigates its orchards and other perennial crops.

\section{Discussion of the results}

The majority of papers dealing with TFP calculation in the agriculture sector investigate it on an aggregate level (for the entire sector), or even on a regional level. This is a possible explanation of the fact that the obtained results for similar periods are often contradictory. Here, we presented a more detailed analysis on the micro (company) level and attained more precise information compared to the aggregate analyses. Namely, if we had remained on the aggregate level, the results would have indicated a TFP which is virtually unchanged over time. To the contrary, the unchanged level of the TFP over time was only coincidently resultant of numerous declining and increasing paths of the TFP related to a particular type of perennial plant. The majority of subclasses demonstrated a productivity decline in the analyzed period, which was compensated for with the productivity increase in olives, spices and pharmaceutical crops.

For the analyzed period, the TFP model demonstrated a statistically important but relatively insignificant impact of subsidy level on the TFP in perennial agriculture in Croatia. Therefore, we failed to refute the basic hypothesis of this paper that government interventions based on subsidies do not lead to technological progress in traditional sectors such as agriculture.

An in-depth analysis of the Croatian perennial sector indicates a low knowledge base and poor investment in education and training, all being part of a horizontal approach in shaping government incentives. These conditions have resulted in excessive usage of labor, inadequate usage of capital and decreasing returns to scale, which also show that more lenient share-of-cost input contribution estimates are misleading in the case of Croatian agriculture, and therefore cannot be used as a 
tool for analysis. Hence, these results could be of great importance for policy makers, as well as a valuable argument for the mainstream theoretical and conceptual strands in the area of industrial policy and government interventions. These new strands highlight the importance of learning, the role of formal and tacit knowledge, discovery and innovation (Aiginger, 2007, p. 314).

\section{Conclusion}

Croatian perennial agriculture sector occupies only $5.5 \%$ of the arable land. While in other European countries this sector yields greater returns than other segments of agriculture, in Croatia it is by $1 / 3$ less productive than the non-perennial production, traditionally the least productive sector of agriculture in the EU. To analyze the reasons for its bad performance, a Cobb-Douglas production function for perennial agriculture in Croatia was estimated using panel data, and the TFP was computed for the observed years (2008-2014) and all nine subsectors (Table 1).

It is found that its overall TFP stagnates in time. A detailed analysis of the dynamics of the TFP per subsector suggests that the oleaginous fruits productivity increased almost sixfold, while production of pharmaceutical herbs and spices was more than doubled during the said period. Other perennial groups stagnated, but other subsectors recorded a significant fall in productivity (cca. $30 \%$ ) in the seven-year period.

Comparison between the theoretical expansion path and the real data has shown that inadequate education led to excessive usage of labor, inadequate usage of capital and decrease in returns to scale. It also revealed that in the Croatian case, the econometric approach produced significantly different results than the share-of-cost approach, which should hence be avoided.

Finally, subsidies displayed almost no effect on the perennial agriculture TFP improvement. Not only did the traditional sectoral policy in the form of direct subsidies lack technological and productive spillovers for the economy, but it also failed to generate the expected productivity growth within the same sector.

Further analyses should also take into account livestock production, hunting and fishing, so as to identify other ways to achieve a more rapid agricultural growth.

\section{References}

Aiginger, K. (2007). Industrial policy: A dying breed or a re-emerging phoenix. Journal of Industry, Competition and Trade, 7(3-4), pp. 297-323.

Armagan, G., and Ozden, A. (2007). Determinations of total factor productivity with Cobb-Douglas production function in agriculture: The case of Aydin-Turkey. J. Applied Sci, 7(4), pp. 499-502.

Aw, B. Y., Chen, X., and Roberts, M. J. (2001). Firm-level evidence on productivity differentials and turnover in Taiwanese manufacturing. Journal of Development Economics, 66(1), pp. 51-86.

Bahovec, V., Erjavec, N. (2009). Uvod u ekonometrijsku analizu, Element, Zagreb

Beeson, P. (1987). Total factor productivity growth and agglomeration economies in manufacturing, 1959-73. Journal of Regional Science, 27(2), pp. 183-199.

Bezlepkina, I. V., Lansink, A. G., and Oskam, A. J. (2005). Effects of subsidies in Russian dairy farming. Agricultural Economics, 33(3), pp. 277-288. 
Bojnec, Š., and Latruffe, L. (2009). Determinants of technical efficiency of Slovenian farms. PostCommunist Economies, 21(1), pp. 117-124.

Brümmer, B., Glauben, T., and Thijssen, G. (2002). Decomposition of productivity growth using distance functions: The case of dairy farms in three European countries. American Journal of Agricultural Economics, 84(3), pp. 628-644.

Cobb, C. W., and Douglas, P. H. (1928). A theory of production. The American Economic Review, 18(1), pp. 139-165.

Croatian Statistical Yearbook (2015). Državni zavod za statistiku, Zagreb.

De Gorter, H., Nielson, D. J., and Rausser, G. C. (1992). Productive and predatory public policies: Research expenditures and producer subsidies in agriculture. American Journal of Agricultural Economics, 74(1), pp. 27-37.

Dholakia, B. H., Dholakia, R. H. (1994). Total factor productivity growth in Indian manufacturing. Economic and Political Weekly, 29(53), pp. 3342-3344.

Državni zavod za statistiku (www.dzs.hr), (accessed 15 Jan 2016)

Echevarria, C. (1998). A three-factor agricultural production function: The case of Canada. International Economic Journal, 12(3), pp. 63-75.

Emvalomatis, G., Oude Lansink, A., and Stefanou, S. (2008, January). An examination of the relationship between subsidies on production and technical efficiency in agriculture: The case of cotton producers in Greece. In 107th EAAE Seminar 'Modelling of Agricultural and Rural Development Policies', Seville, Spain (Vol. 29).

Enaami, M. E., Mohamed, Z., and Ghani, S. A. (2013). Model development for wheat production: Outliers and multicollinearity problem in Cobb-Douglas production function. Emirates Journal of Food and Agriculture, 25(1), p. 81.

Fan, S., Gulati, A., and Thorat, S. (2008). Investment, subsidies, and pro-poor growth in rural India. Agricultural Economics, 39(2), pp. 163-170.

Guyomard, H., Latruffe, L., and Le Mouël, C. (2006). Technical efficiency, technical progress and productivity change in French agriculture: Do subsidies and farms' size matter?. 96th EAAE Seminar (pp. 1011).

Herceg, T., Vrankić, I., Galetić, F. (2016, April). Technological progress in Croatian non-perennial agriculture. OFEL Conference Proceedings, Dubrovnik.

Hseu, J. S., and Shang, J. K. (2005). Productivity changes of pulp and paper industry in OECD countries, 1991-2000: A non-parametric Malmquist approach. Forest Policy and Economics, 7(3), pp. 411422.

Ketels, C. H. (2006). Michael Porter's competitiveness framework - Recent learnings and new research priorities. Journal of Industry, Competition and Trade, 6(2), pp. 115-136.

Kroupová, Z., and Malý, M. (2010). Analýzanástrojůzemědělskédotačnípolitikyaplikaceprodukčníchfunkcí. Politickáekonomie, 6, pp. 778-798.

Latruffe, L., Davidova, S., and Balcombe, K. (2008). Productivity change in Polish agriculture: An illustration of a bootstrapping procedure applied to Malmquist indices. Post-Communist Economies, 20(4), pp. 449-460. 
Palmero, A., J. H. (2004). Total factor productivity and growth in Mexican manufacturing during the period 1929-1944, Los Angeles: University of California.

Pereira, M. F., Silveira, J. S. T. D., Lanzer, E. A., and Samohyl, R. W. (2002). Productivity growth and technological progress in the Brazilian agricultural sector. Pesquisa Operacional, 22(2), pp. 133-146.

Parlinska, M., and Dareev, G. (2011). Application of production function in agriculture. Quantitative Methods in Economics, 12(1), p.119.

Rodrik, D. (2004). Industrial policy for the twenty-first century. UNIDO.

San Juan Mesonada, C., Sperlich, S., Murillo, C., and Kleinhans, W. (2005). Efficiency, subsidies and environmental adaptation of animal farming under CAP. EconWPA.

Simiyu, C. (2015). Explaining the relationship between public expenditure and economic growth in Kenya using vector error correction model (VECM). International Journal of Economic Sciences, 4(3), pp. 1933.

Swinnen, J. F., and Vranken, L. (2010). Reforms and agricultural productivity in Central and Eastern Europe and the Former Soviet Republics: 1989-2005. Journal of Productivity Analysis, 33(3), pp. 241-258.

Tonini, A., and Jongeneel, R. (2006). Is the collapse of agricultural output in the CEECs a good indicator of economic performance? A total factor productivity analysis. Eastern European Economics, 44(4), pp. 32-59.

Virmani, A. (2002). Sources of India's economic growth: Trends in total factor productivity. Indian Council for Research on International Economic Relations, New Delhi (ICRIER Working Paper 131).

Weber, W. L., and Domazlicky, B. R. (1999). Total factor productivity growth in manufacturing: A regional approach using linear programming. Regional Science and Urban Economics, 29(1), pp. 105-122.

Wen, G. J. (1993). Total factor productivity change in China's farming sector: 1952-1989. Economic Development and Cultural Change, 42(1), pp. 1-41.

Wong, F. C., and Gan, W. B. (1994). Total factor productivity growth in the Singapore manufacturing industries during the 1980s. Journal of Asian Economics, 5(2), pp. 177-196. 